\title{
When patients won't leave or families won't let them
}

\author{
David Oliver consultant in geriatrics and acute general medicine
}

Berkshire

All clinicians in acute medical specialties probably see some patients who are medically stable but either don't want to leave hospital or have relatives who actively or passively stop them leaving. We worry about how to handle this appropriately.

I've argued that doctors should rightly sometimes keep patients in a little longer if the right community services aren't yet in place, or if they don't feel quite well enough, if their carers are concerned, or if a move to another setting would upset them. But every decision we make about admission, discharge, or bed use has opportunity costs for other patients in need. Prolonging stays also exposes patients to many risks inherent in admission to hospital. We should minimise the number of days patients stay when hospital is no longer adding unique value.

We see inpatients whom we would never admit at the hospital front door as they are now, however sick they were initially. They are often receiving no treatment that requires the full facilities of an acute care setting. We also see those who have regained their former level of functional independence and just don't want to leave. They would happily stay longer and may not be keen on any community support we recommend, especially if it's means tested social care. Patients who are fearful, lonely, and isolated at home often enjoy the company and support-but an acute care bed is an expensive way to provide that.

Families can also obstruct patients' departure. Hands-on carers play a vital, stressful, and under-recognised role, and we must always involve them fully and respect their needs. ${ }^{12}$ But sometimes relatives who are not so intimately involved can hinder transition from hospital.

Often in my job as a geriatrician I see older people who are perfectly capable of understanding and accepting the risk of falling or struggling to cope when they get back home. But their free will is obstructed by relatives who would prefer to wrap them in cotton wool, letting them stay in hospital indefinitely and deferring any decisions, or be moved to a community hospital or care home they neither want nor need. However, life isn't free of risk, older people have a right to accept this, and no hospital discharge can be made perfectly safe, nor all readmissions prevented. ${ }^{34}$ It isn't a "hospital safe" versus "home risky" zero sum game.
Relatives may refuse to allow access to the patient's home or delivery of equipment or keypads to allow carers in, or they may dispute assessments of occupational therapists or physiotherapists. We also encounter families who want to use hospital admission to solve longstanding problems in the patient's own home-for instance, fitting stair lifts or fixing heating.

When it comes to organising social care at home or in residential care, we need the family's collaboration in attending meetings and speaking to social workers. We need their help in completing financial assessments, accessing funds, considering care homes, or accepting that sometimes payment is required to move the patient on and that the NHS hospital doesn't control those rules. Drawn-out appeals over continuing healthcare funding shouldn't require the patient to be stuck in hospital while the NHS, local authority, and family argue over money. ${ }^{56}$

We need experienced, well trained staff to handle such scenarios with patience and sensitivity, but at some point a line is crossed where we have a responsibility to be direct and assertive. Our duty of care is primarily to the patient and then to all patients needing beds. And NHS hospitals are currently running at $95 \%$ bed occupancy. ${ }^{7}$

How much support will we then get when complaints come in? I would suggest that every trust have a standard letter, co-signed by the chief executive, chief operating officer, medical director, and nursing directors, that staff can hand to families. The letter should point out that NHS acute care beds are a precious resource for everyone in need and that families should support the clinical teams completely in doing the right thing for the system.

Competing interests: See bmj.com/about-bmj/freelance-contributors/david-oliver. Provenance and peer review: Commissioned; not externally peer reviewed.

Oliver D. David Oliver: welcoming carers on to the wards. BMJ 2015;351 :h4959.26385852 2 Oliver D. David Oliver: Taking carers for granted. BMJ 2017;357:j1523. 10.1136/bmj.j1523 28377428

3 Healthwatch. Safely home: people's experiences of leaving care. https://www.healthwatch. co.uk/safely-home-peoples-experiences-leaving-care.

4 Leppin AL, Gionfriddo MR, Kessler M, etal . Preventing 30-day hospital readmissions: a systematic review and meta-analysis of randomized trials. JAMA Intern Med 2014;174:1095-107. 10.1001/jamainternmed.2014.1608 24820131 
5 Oliver D. David Oliver: NHS continuing care is a mess. BMJ 2016;354:i4214. $10.1136 / \mathrm{bmj} .1421427495806$

6 National Audit Office. Discharging older patients from hospital. https://www.nao.org.uk/ report/discharging-older-patients-from-hospital.
7 PublicFinance. Hospital bed occupancy hit high of $96 \%$ in February. www.publicfinance. co.uk/news/2018/03/hospital-bed-occupancy-hit-high-96-february.

Published by the BMJ Publishing Group Limited. For permission to use (where not already granted under a licence) please go to http://group.bmj.com/group/rights-licensing/ permissions 